INVITED REVIEW

\title{
Controversies in radioiodine therapy: relation to ophthalmopathy, the possible radioprotective effect of antithyroid drugs, and use in large goitres
}

\author{
S J Bonnema, L Bartalena ${ }^{1}$, A D Toft ${ }^{2}$ and L Hegedüs \\ Department of Endocrinology and Metabolism, Odense University Hospital, DK-5000 Odense, Denmark, ${ }^{1}$ Department of Endocrinology, \\ Ospedale di Circolo, University of Insubria, 21100 Varese, Italy and ${ }^{2}$ Endocrine Clinic, Royal Infirmary, Edinburgh EH3 9YW, UK \\ (Correspondence should be addressed to Steen Bonnema; Email: steen.bonnema@dadlnet.dk)
}

\begin{abstract}
In routine use for more than 50 years, radioiodine $\left({ }^{131} \mathrm{I}\right)$ is generally considered safe and devoid of major side effects. Therefore, it is surprising that relatively many aspects of radioiodine therapy are controversial, as illustrated by recent international questionnaire studies. Our review aims at highlighting three of these areas - namely, the influence of ${ }^{131}$ I on the course of Graves' ophthalmopathy, the possible radioprotective effects of antithyroid drugs, and the use of ${ }^{131} \mathrm{I}$ in large goitres.

${ }^{131}$ I therapy carries a small (but definite) risk of causing progression of Graves' ophthalmopathy. Identification of risk factors (thyroid dysfunction, high level of thyroid-stimulating hormone (TSH) receptor antibodies, cigarette smoking) allows the identification of patients at risk and the institution of concomitant glucocorticoid treatment, thereby hindering progression of eye disease.

On the basis, largely, of retrospective data, it appears that carbimazole (or methimazole), if stopped 3-5 days before treatment, does not influence the outcome of ${ }^{131}$ I therapy. Simultaneous thyrostatic medication most probably reduces the efficacy of ${ }^{131} \mathrm{I}$, as does restarting it within 7 days. Propylthiouracil seems to have a more prolonged radioprotective effect than carbimazole.

Surgery is the treatment of first choice in patients with a large goitre. However, in the case of patient ineligibility or preference, ${ }^{131}$ I therapy may be an option. The treatment has a favourable effect on tracheal compression and inspiratory capacity, but the reduction in thyroid volume is only 30-40\%. Inpatient treatment, necessitated by the large doses, makes the treatment cumbersome.

Controversy related to radioiodine therapy is mainly based on the lack of adequate prospective randomised studies comparing efficacy, side effects, cost and patient satisfaction.

European Journal of Endocrinology 147 1-11
\end{abstract}

\section{Introduction}

Radioiodine $\left({ }^{131} \mathrm{I}\right)$, in routine use for more than 50 years for the treatment of toxic goitre, but with a much shorter history of use for non-toxic goitre, is generally considered safe, cheap and devoid of major side effects. Thus major issues should have been clarified, leading to a consensus long ago. While this is undoubtedly true for some aspects of radioiodine therapy, it certainly is not for others. Indeed, questionnaire studies amongst both European and North American thyroidologists have disclosed major differences when it comes to the management of several thyroid disorders, including Graves' disease (1, 2), Graves' ophthalmopathy (3), the solitary thyroid nodule $(4,5)$, and multinodular non-toxic goitre $(6$, 7). In relation to ${ }^{131} \mathrm{I}$, a number of issues have yet to be clarified. This review highlights the content of a recent symposium held at the annual meeting of the European Thyroid Association (ETA) in Warsaw,
August 2001, dealing with 'Controversies in ${ }^{131} \mathrm{I}$ therapy'. We will cover three topics:

(i) ${ }^{131} \mathrm{I}$ therapy and the course of Graves' ophthalmopathy.

(ii) The use of antithyroid drugs in relation to ${ }^{131} \mathrm{I}$ therapy.

(iii) ${ }^{131}$ I therapy in large goitres.

We emphasise that the views expressed in this paper represent neither a consensus nor the official position of the ETA, or any other organisation, but are the opinions of experts in the field entrusted with organising the symposium.

\section{${ }^{131}$ I therapy and the course of Graves' ophthalmopathy}

Graves' ophthalmopathy may develop before, concomitantly with, or even after, the onset of hyperthyroidism 
(8). In the latter situation, ophthalmopathy occurs after institution of treatments aimed at controlling or curing hyperthyroidism. This makes it difficult to understand whether the observed ocular changes are related to the natural history of eye disease or are associated with the modality of treatment for hyperthyroidism. Accordingly, the available information on the effects of treatment for hyperthyroidism on the ophthalmopathy is conflicting and often contradictory (9).

In spite of these limitations, it is widely accepted that treatment of hyperthyroidism with antithyroid drugs does not affect the course of the ophthalmopathy (10). Likewise, as also recently shown by a prospective casecontrol study, near-total thyroidectomy is not associated with substantial variations in ocular conditions (11).

The available information concerning the effect of ${ }^{131}$ I therapy on the ophthalmopathy is much more controversial, supporting both the concept that ${ }^{131}$ I does not cause progression of eye disease (12) and the idea that this treatment may be somehow detrimental for the ophthalmopathy $(13,14)$. Conflicting results are, at least in part, related to the frequent retrospective and non-randomised nature of most studies, to the lack of adequate control groups, and to the non-standardised assessment of ocular changes (14). Few reports of prospective, randomised studies are available on this issue (see below).

\section{Non-randomised studies on the relation between ${ }^{131}$ I therapy and the course of the ophthalmopathy}

In a study of 433 patients, development or progression of the ophthalmopathy occurred in 15 cases (3\%) after

${ }^{131}$ I therapy, comparing favourably with the outcome of antithyroid drugs or thyroidectomy (15). Hamilton et al. (16) observed that, after ${ }^{131}$ I therapy, exacerbation of pre-existing ophthalmopathy $(18 \%)$ was more common than the occurrence of new ophthalmopathy (5\%). Similar results were reported by Pequegnat et al. (17). Kriss et al. (18) observed an increase in proptosis in 8 of 24 patients $(33 \%)$ treated with ${ }^{131} \mathrm{I}$, and Hetzel et al. (19) reported the exacerbation of the ophthalmopathy in 9 of 17 patients (53\%). Barth et al. (20) retrospectively evaluated the records of 89 patients treated with ${ }^{131} \mathrm{I}$, and observed a progression of the ophthalmopathy in 17 cases (19\%). Another study showed progression of eye disease in 6 of 24 patients treated with ${ }^{131} \mathrm{I}(25 \%)$, but in none of those submitted to thyroid surgery (21). Kung et al. (22) observed an exacerbation of ocular conditions in 27 of 114 patients $(24 \%)$ receiving ${ }^{131} \mathrm{I}$ therapy, most probably in patients whose post- ${ }^{131} \mathrm{I}$ hypothyroidism was not promptly corrected.

At variance with these, other studies failed to find substantial variations in ocular conditions after ${ }^{131} \mathrm{I}$ therapy for hyperthyroidism. Aron-Rosa et al. (23) reported only 22 cases of eye disease progression in 604 patients $(4 \%)$ treated with ${ }^{131}$ I. Sridama \& DeGroot (24) retrospectively evaluated 537 patients treated for hyperthyroidism, and found no differences either in the rate of occurrence of new ophthalmopathy after antithyroid drug treatment $(7 \%)$, thyroidectomy $(7 \%)$ or ${ }^{131}$ I therapy $(5 \%)$, or in the rate of progression of pre-existing ophthalmopathy, which was more frequent, but apparently unrelated to the type of treatment for hyperthyroidism (antithyroid drugs 19\%; thyroidectomy 19\%; ${ }^{131}$ I 23\%). Abe et al. (25) reported progression of the ophthalmopathy in $7(10 \%)$, improvement in $2(3 \%)$, and no changes in $58(87 \%)$ of 67 Graves' patients treated with ${ }^{131}$ I therapy. In this last study, the course of the ophthalmopathy was worse after ${ }^{131}$ I therapy than after subtotal thyroidectomy. Manso et al. (26), in a prospective, nonrandomised study enrolling 22 patients, found no progression of the ophthalmopathy. The results of non-randomised studies, summarised in Fig. 1, indicate a range of progression of the ophthalmopathy after radioiodine therapy in $3-53 \%$ of patients.

\section{Randomised studies on the relation between ${ }^{131}$ I therapy and the course of the ophthalmopathy}

The results of the few available randomised studies are more uniform, showing progression of Graves' ophthalmopathy after ${ }^{131}$ I therapy in a proportion of patients

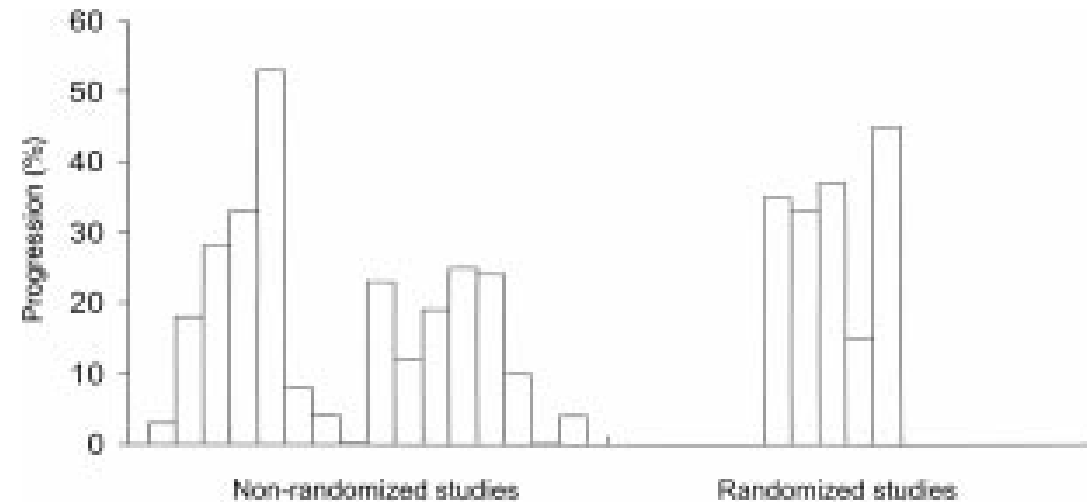

www.eje.org
Figure 1 Progression of Graves' ophthalmopathy after radioiodine therapy for hyperthyroidism caused by Graves' disease. Results of non-randomised and randomised studies. Each bar represents one study. Percentage of progression in non-randomised studies: $3-53 \%$. Compiled from the literature (see reference (10) for details). 
ranging from 15 to $37 \%$ (14) (Fig. 1). In a pilot study, patients were randomly assigned to treatment with either ${ }^{131} \mathrm{I}$ alone or ${ }^{131}$ I given concomitantly with a short course of prednisone therapy. Worsening of the ophthalmopathy occurred in 9 of 26 patients (35\%) receiving ${ }^{131} \mathrm{I}$ alone, whereas progression did not occur (and pre-existing ophthalmopathy improved in most cases) in patients receiving concomitant glucocorticoid treatment (27). This study did not include a control group treated with thionamides. In a subsequent, large study, Tallstedt et al. (28) reported that the rate of occurrence or progression of the ophthalmopathy was similar after antithyroid drug treatment (4 of 38 patients, $10 \%$ ) or thyroidectomy ( 6 of 37 patients, $16 \%)$, but was significantly greater after ${ }^{131}$ I therapy (13 of 39 patients, 33\%). In a prospective, randomised, controlled study (29), 23 of 150 patients treated with ${ }^{131}$ I therapy showed progression of the ophthalmopathy, which was transient in 15 , and permanent in $8(5 \%)$, who subsequently needed treatment for eye disease. This progression did not occur in the group treated with ${ }^{131}$ I therapy and glucocorticoids (Fig. 2). Treatment with methimazole was not associated with changes in the ophthalmopathy (29). Vàzquez-Chavez et al. (30) randomly assigned 40 patients to treatment with either radioiodine or thyroidectomy: on the basis of exophthalmometer readings only, no differences of either treatment were observed with regard to the effect on the ophthalmopathy.

\section{Pathogenesis of ${ }^{131}$ I-associated progression of the ophthalmopathy}

The progression of the ophthalmopathy after ${ }^{131} \mathrm{I}$ therapy is probably related to the release of thyroid antigens from the radiation-damaged thyroid gland, with subsequent enhancement of autoimmune responses towards antigens shared by the thyroid and the orbit (14). ${ }^{131}$ I therapy is followed by the release

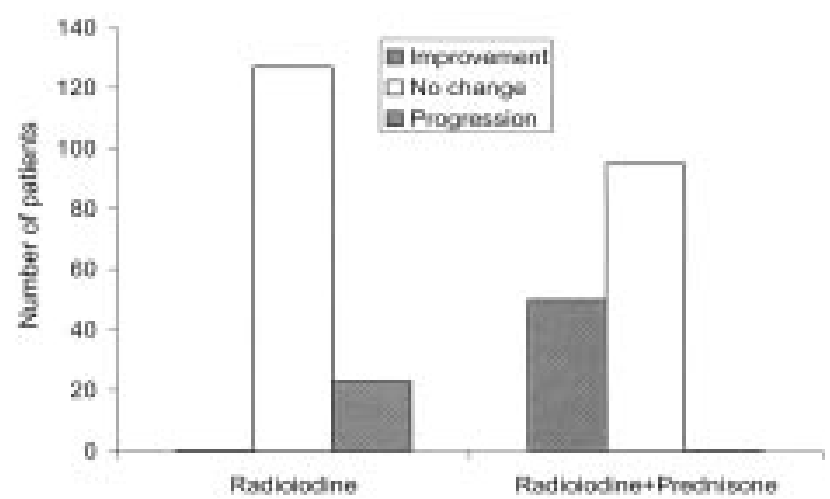

Figure 2 Outcome of Graves' ophthalmopathy after treatment with radioiodine alone or radioiodine and prednisone. Derived from Bartalena et al. (29). of thyroperoxidase in the bloodstream (31), and by an increase in the activity of thyroid-stimulating hormone (TSH) receptor antibodies (32). In addition, peripheral blood T-cell activation (33) and a prolonged increase $(>2$ years) in thyroid autoantibody production (34) have been described after ${ }^{131}$ I therapy for Graves' hyperthyroidism.

It is possible that although, in the short term, ${ }^{131} \mathrm{I}$ therapy bears the risk of an aggravation of the ophthalmopathy, in the long term it may have beneficial effects on eye disease, as a result of thyroid antigen deprivation and removal of intrathyroid activated T-lymphocytes that are presumably also involved in the pathogenesis of the ophthalmopathy. This hypothesis remains to be proven.

\section{Risk factors for progression of Graves' ophthalmopathy after ${ }^{131}$ I therapy}

Progression of the ophthalmopathy after ${ }^{131}$ I therapy occurs only in a minority of patients (29). This suggests that other risk factors or cofactors must contribute to this outcome. Some of these factors have been identified. In one study, progression of the ophthalmopathy occurred in 17 of 72 patients $(24 \%)$ with pre-existing ophthalmopathy and only in 6 of 78 patients $(8 \%)$ without eye involvement before ${ }^{131}$ I therapy (29). In addition, this negative outcome of ${ }^{131} \mathrm{I}$ therapy was quite rare in non-smokers (4 of 68 patients, 6\%) and much more frequent among smokers (19 of 82 patients, 23\%) (35). Severity of pre- ${ }^{131}$ I hyperthyroidism seems to be another risk factor, because aggravation of the ophthalmopathy was reported to be more likely in patients who had greater serum thyroid hormone concentrations before treatment (28). High serum TSH (22) or TSH receptor antibody levels (36) might also play a part in the exacerbation of the ophthalmopathy after ${ }^{131}$ I therapy, but this remains to be proven. The importance of restoring normal thyroid status is emphasised by the observation that the rate of progression of the ophthalmopathy after administration of ${ }^{131} \mathrm{I}$ was greater in patients whose post- ${ }^{131} \mathrm{I}$ hypothyroidism was corrected late than in those in whom replacement of L-thyroxine $\left(\mathrm{T}_{4}\right)$ was instituted promptly (37).

\section{Guidelines for ${ }^{131}$ I therapy in patients with Graves' ophthalmopathy}

In patients who have non-severe Graves' ophthalmopathy, it is advisable that ${ }^{131} \mathrm{I}$ therapy be administered under glucocorticoid protection (prednisone 0.4$0.5 \mathrm{mg} / \mathrm{kg}$ body weight for 1 month, gradually withdrawn over 3 months). If no signs or symptoms of the ophthalmopathy are present before treatment, ${ }^{131} \mathrm{I}$ therapy may not require concomitant glucocorticoid therapy, provided other risk factors (especially cigarette smoking) are absent. In patients with severe 
ophthalmopathy, ${ }^{131}$ I therapy can be carried out, but eye disease requires prompt and independent, appropriate therapeutic measures, such as high-dose glucocorticoids or orbital radiotherapy, or both, or orbital decompression (38). Treatment for the ophthalmopathy can be started immediately after radioiodine therapy. Alternatively, while hyperthyroidism is temporarily controlled by antithyroid drugs, ophthalmopathy is treated by appropriate therapies, and radioiodine administration is postponed until treatment for the ophthalmopathy has been completed.

\section{Concluding remarks}

${ }^{131}$ I therapy seems to carry a small (but definite) risk of causing progression of Graves' ophthalmopathy (39). This effect of ${ }^{131} \mathrm{I}$ therapy apparently modified the approach of many endocrinologists as to the use of ${ }^{131} \mathrm{I}$ in the management of hyperthyroidism. In a recent survey of European endocrinologists, the selected modality of treatment of hyperthyroidism in case of recurrence after a first course of antithyroid drug treatment was thyroidectomy (43\% of respondents), a second course of thionamides $(32 \%)$, and ${ }^{131} \mathrm{I}$ (only $25 \%$ of respondents) (3). Thus, if ablative therapy was chosen, surgery rather than ${ }^{131} \mathrm{I}$ was the more commonly selected modality of treatment. However, the risk of progression of the ophthalmopathy after ${ }^{131} \mathrm{I}$ should not be used as an argument to avoid this treatment, when appropriate. In fact, identification of risk factors allows the identification of patients in whom progression of the ophthalmopathy is more likely. In at-risk patients, concomitant glucocorticoid therapy avoids progression of eye disease. In addition, as mentioned above, ablation of the thyroid by ${ }^{131} \mathrm{I}$ may, in the long term, prove beneficial for the ophthalmopathy.

\section{The use of antithyroid drugs in relation to ${ }^{131}$ I therapy}

Relief of symptoms of hyperthyroidism between the initial consultation and administration of ${ }^{131} \mathrm{I}$ and for the following 6-8 weeks can usually be achieved to a significant extent with a $\beta$-adrenoceptor antagonist, such as propranolol. In older patients, in those with severe hyperthyroidism or with cardiovascular complications, it is common practice to achieve euthyroidism first, in order to prevent the consequences of the rare, but well-recognised, worsening of thyrotoxicosis, caused by irradiation-induced leakage of stored thyroid hormones within the first few days (40). Antithyroid drugs, if stopped shortly before ${ }^{131}$ I therapy, do not prevent a transient increase in serum thyroid hormone concentrations, but any increase is from a lower baseline (41), and of no clinical significance. This pattern is consistent with the observation that antithyroid drug therapy can reduce the content of both tri-iodothyronine and $\mathrm{T}_{4}$ in the thyroid gland of patients with Graves' disease by over 95\% (42). In other patients, prior treatment with antithyroid drugs may simply be a consequence of change of mind about the most appropriate treatment of the hyperthyroidism.

There has been considerable experience of prescribing antithyroid drugs before or after ${ }^{131} \mathrm{I}$ therapy since the first description of their adjunctive role more than 50 years ago (43). Indeed, a survey of members of the American Thyroid Association found that 31\% of correspondents prescribe antithyroid drugs before and $40 \%$ after ${ }^{131} \mathrm{I}$ (2). However, there remains controversy about whether antithyroid drugs influence the outcome of ${ }^{131}$ I treatment, and how long any effect persists. To some extent, the confusion reflects the retrospective nature of many studies (however large), patient selection and the likelihood that the antithyroid drug was given before ${ }^{131}$ I therapy to those with the more severe hyperthyroidism, the varied ${ }^{131}$ I dose regimen, and the failure to report the results of thyroid function tests at the time of ${ }^{131} \mathrm{I}$ administration. This last omission is important because, for example, increased serum TSH as a result of excessive antithyroid therapy or the presence of significant concentrations of stimulating TSH receptor antibodies will alter iodine kinetics, with the potential to reduce the effective dose of ${ }^{131}$ I retained within the gland.

\section{Propylthiouracil}

The antithyroid agent, thiourea, and other sulphydryl (-SH)-containing compounds have been shown to be radioprotective, reducing the death rate in wholebody irradiated mice and in irradiated bacteria (44, 45). Both methylthiouracil, which is no longer used, and propylthiouracil contain an - $\mathrm{SH}$ radical, and its radioprotective effect was the explanation given for the significant reduction in one-dose cure rates when patients were pretreated with methylthiouracil until 7 days before ${ }^{131} \mathrm{I}$, compared with those given no such therapy (28.6\% compared with $75.5 \%)$. This difference could not be accounted for by the aetiology of the hyperthyroidism or the biological half-lives of the therapeutic doses of ${ }^{131} \mathrm{I}$. Increasing the therapy dose by $25 \%$ in patients pretreated with the antithyroid drug nullified the difference in response rate (46).

In a contemporaneous study, propylthiouracil was either still being taken at the time of ${ }^{131}$ I therapy or had been discontinued for different periods of time beforehand. The failure rate was greatest in those in whom the propylthiouracil was not stopped. It only became similar to those treated with ${ }^{131} \mathrm{I}$ alone if more than 15 days had elapsed between the last dose of antithyroid drug and administration of ${ }^{131} \mathrm{I}$ (47). The basis for stopping antithyroid treatment was not clear. It is more than likely that patients with the mildest degrees of hyperthyroidism initially were 
over-represented in the group receiving no adjunctive antithyroid drugs. In the most recent retrospective studies, the radioprotective effect of propylthiouracil was shown to persist for at least 7 days $(48,49)$, and as long as 55 days (50).

Despite the design failings of the various studies, it does appear that propylthiouracil renders the thyroid gland relatively resistant to ${ }^{131}$ I therapy. Unless the drug can be withdrawn on clinical grounds for some 2 weeks before ${ }^{131} \mathrm{I}$ administration, it may be necessary to use a larger dose of isotope, recognising that an 'ablative' dose of $555 \mathrm{MBq}(15 \mathrm{mCi})$ would probably overcome any inherent radioresistance in most cases of Graves' disease.

\section{Carbimazole}

There are two similar studies (Table 1), conducted more than 30 years apart, which demonstrate that pretreatment with carbimazole or methimazole does not reduce the effectiveness of ${ }^{131}$ I therapy in patients with Graves' disease, as long as the antithyroid drug is stopped for up to 4 days beforehand $(51,52)$. The more recent of these reports is a randomised, prospective study and is, therefore, unique. What is interesting is the greater 'cure' rate in the later study, which is unlikely to be entirely due to the greater calculated ${ }^{131} \mathrm{I}$ dose of $200 \mu \mathrm{Ci} / \mathrm{g}$ of thyroid tissue, and may relate to differences in iodine status between patients in Brazil and England.

Simultaneous treatment with carbimazole at the time of ${ }^{131}$ I therapy was found to increase the possibility of treatment failure more than fivefold (53). In the same report, it was suggested that it might be necessary to discontinue carbimazole or methimazole for only $24 \mathrm{~h}$, but the number of patients involved was small.

The influence of antithyroid drugs on outcome if given after ${ }^{131} \mathrm{I}$ therapy has received less attention, but the same anxieties about patient selection prevail. Thus, in a large retrospective study of 206 patients, ${ }^{131}$ I was either given alone or followed, for 5-14 days or more, by methimazole or propylthiouracil. Those patients starting an antithyroid drug within 7 days of ${ }^{131}$ I therapy had a significantly greater incidence of continuing hyperthyroidism. Unfortunately, no distinction was made between patients taking methimazole and those taking propylthiouracil (54).

\section{Why does propylthiouracil seem to confer more resistance to ${ }^{131}$ I therapy?}

In the past, this observation was explained by the radioprotective effects of the sulphydryl group of propylthiouracil, which was believed not to be present in carbimazole or methimazole (51). There must be other explanations. Although propylthiouracil has a shorter half-life in serum than has methimazole (55), propylthiouracil and its metabolites are concentrated and retained in human thyroid more than methimazole and its metabolites $(56,57)$. If, for example, the radioprotective effect of the thionamides is distinct from their inhibition of thyroid hormone synthesis, the therapeutic dose of propylthiouracil being 10 times greater than that of methimazole may be significant.

\section{Other issues}

There is anecdotal evidence that patients maintained on antithyroid drugs for many years before being treated with ${ }^{131} \mathrm{I}$ often fail to respond to repeated doses of $400 \mathrm{MBq}(11 \mathrm{mCi})$ or more. This apparent radioresistance is likely to be a consequence of a relative iodine deficiency within the gland and resultant increase in thyroidal iodine turnover rate, reducing the anticipated dose of radiation. The duration of therapy required to involve such a mechanism is not known, but presumably will also depend upon the iodine status of the population being treated.

Attention has been focused almost exclusively on patients with Graves' disease. From time to time, patients with hyperthyroidism caused by nodular goitre are pretreated with antithyroid drugs. Although the same principles concerning the radioprotective effects of these drugs should apply, any overtreatment sufficient to restore serum TSH to normal or to induce thyroid failure will result in stimulation of the previously dormant paranodular tissue and increase the rate of post- ${ }^{131}$ I hypothyroidism.

Table 1 Comparison of two studies showing that pretreatment with carbimazole (CBZ) or methimazole (MMI) until 3-5 days before ${ }^{131}$ I therapy for Graves' disease does not affect outcome.

\begin{tabular}{|c|c|c|c|c|c|c|c|}
\hline \multirow[b]{2}{*}{ Study } & \multirow[b]{2}{*}{ Treatment } & \multirow{2}{*}{$\begin{array}{c}\text { Time off } \\
\text { antithyroid drug } \\
\text { (days) }\end{array}$} & \multirow{2}{*}{$\begin{array}{l}\text { No. of } \\
\text { patients }\end{array}$} & \multirow{2}{*}{$\begin{array}{l}\text { Calculated } \\
\text { dose of }{ }^{131} \mathbf{I} \\
(\mu \mathrm{Ci} / \mathrm{g})\end{array}$} & \multicolumn{3}{|c|}{$\begin{array}{c}\text { Thyroid status at } 1 \text { year } \\
(\%)\end{array}$} \\
\hline & & & & & Eu. & Hypo. & Hyper. \\
\hline Retrospective (51) & $\underset{131}{\mathrm{CBZ}}+{ }^{131} \mathrm{I}$ & $3-5$ & $\begin{array}{l}83 \\
98\end{array}$ & $150^{*}$ & $\begin{array}{l}63 \\
67\end{array}$ & $\begin{array}{l}14 \\
13\end{array}$ & $\begin{array}{l}23 \\
20\end{array}$ \\
\hline Prospective, randomized (52) & $\underset{131}{\mathrm{MMI}}+{ }^{131} \mathrm{I}$ & 4 & $\begin{array}{l}29 \\
32\end{array}$ & 200 & $\begin{array}{l}31 \\
28\end{array}$ & $\begin{array}{l}55 \\
56\end{array}$ & $\begin{array}{l}14 \\
16\end{array}$ \\
\hline
\end{tabular}

${ }^{*}$ Patients with palpated gland size of $>70 \mathrm{~g}$ received $300 \mu \mathrm{Ci} / \mathrm{g}$ as calculated dose of ${ }^{131} \mathrm{I}$. 


\section{Concluding remarks}

It is remarkable that, despite the widespread use of antithyroid drugs before and after ${ }^{131} \mathrm{I}$ therapy for Graves' disease, the only certainty would appear to be that carbimazole (or methimazole), if stopped 3-5 days before treatment, will not influence the outcome. It is likely that simultaneous thyrostatic medication reduces the efficacy of ${ }^{131} \mathrm{I}$, as does re-starting it within 7 days. Propylthiouracil would seem to have a more prolonged radioprotective effect than carbimazole, necessitating higher doses of ${ }^{131} \mathrm{I}$, unless discontinued at least 2 weeks beforehand.

\section{${ }^{131}$ I therapy in large goitres}

In large series of thyroidectomised patients, more than $30 \%$ have a goitre larger than $100 \mathrm{~g}(58)$. Glands of this size are typically multinodular, and as the prevalence of malignancy in such goitres is the same as in the solitary thyroid nodule (59), fine-needle aspiration biopsy should be performed in dominant or large nodules (60). In substernal goitres not accessible for biopsy, surgery should be performed, particularly in case of factors raising suspicion of thyroid malignancy. The next question is which treatment to offer. In smaller goitres, $\mathrm{L}-\mathrm{T}_{4}$ suppressive therapy is used by many clinicians $(6,7)$, in spite of little evidence in support of this strategy. The few randomised studies performed have shown no (61) or only a very modest effect (62), and in large goitres $\mathrm{L}-\mathrm{T}_{4}$ is probably even less effective. Faced with a large or substernal goitre, most clinicians turn to surgery $(6,7)$. Without dispute, the advantage of surgery is the significant and prompt reduction of the goitre. However, recurrence is seen in $15-40 \%$ of patients with long-term follow-up $(63,64)$, and postoperative complications are clearly more frequent in cases of a large goitre, previous neck surgery or substernal extension of the goitre (58). In addition, some patients are not suitable for surgery because they have complicating disorders. In these situations, ${ }^{131} \mathrm{I}$ therapy may be considered, even in the patient with a very large goitre.

\section{How should the volume of a large goitre be measured?}

If ${ }^{131}$ I therapy is considered, an accurate estimation of goitre size is important for the dose calculation. Neck palpation is notoriously imprecise $(65,66)$. Ultrasound - adopted by thyroidologists as the primary imaging tool $(6,7)$ - underestimates the volume of the very large goitre by approximately $20 \%$ compared with magnetic resonance imaging (MRI) (67), and use of this method is furthermore hampered by the substernal extension frequently encountered in these patients. Also, thyroid ${ }^{131} \mathrm{I}$ scintigraphy generally underestimates the size of large goitres compared with com- puted tomography (CT) or MRI $(68,69)$. In contrast, the precision of MRI in measuring large goitres is high, with inter- and intra-observer coefficients of variation of $2-4 \%(67,68)$. Thus, with goitres larger than $150-200 \mathrm{ml}$ or with an intrathoracic extension, MRI (or alternatively CT) should be preferred to other methods.

\section{Efficacy of ${ }^{131}$ I therapy for reduction of the large goitre}

${ }^{131}$ I therapy for goitre reduction has been used for several years, even in euthyroid patients. The efficacy of this treatment is almost exclusively documented by non-controlled trials, but nevertheless results have been very consistent. In toxic multinodular goitres, in which case the primary goal is to cure hyperthyroidism, Nygaard et al. (70) found a goitre reduction of $43 \%$ within 2 years. Similar results have been obtained in studies of the non-toxic multinodular goitre (71-73), with reductions ranging from 40 to $60 \%$. The superiority of ${ }^{131} \mathrm{I}$ over L-T $\mathrm{T}_{4}$ has recently been shown in a randomised trial by Wesche et al. (61). In that study, ${ }^{131} \mathrm{I}$ induced a goitre shrinkage of $44 \%$ within 2 years, whereas $\mathrm{L}_{-} \mathrm{T}_{4}$ was found to have no effect and was associated with a significant bone loss and other adverse effects also. Only a few studies specifically addressing the use of ${ }^{131} \mathrm{I}$ therapy in very large goitres have been performed. None of these included a control group. Kay et al. (74), Hamburger \& Hamburger (75) and Verelst et al. (76) all reported that high-dose ${ }^{131} \mathrm{I}$ therapy resulted in a significant reduction in goitre size. However, only a clinical or a scintigraphic evaluation was used in those studies. In three other studies $(69,77,78)$, more valid methods of goitre monitoring were used - either CT or MRI. de Klerk et al. (69) treated 27 patients with large non-toxic goitres (mean volume $194 \mathrm{ml})$. The reduction was $34 \%$ on average after 1 year. Huysmans et al. (78) treated 19 toxic or euthyroid patients with a mean goitre volume of $269 \mathrm{ml}$. In that study, $\mathrm{L}_{-} \mathrm{T}_{4}$ was routinely used after treatment, and a $40 \%$ reduction was obtained after 1 year. Finally, Bonnema et al. (77) found a reduction of $34 \%$ after highdose ${ }^{131}$ I therapy in 23 toxic or euthyroid patients with an initial mean goitre volume of $311 \mathrm{ml}$. In these last two studies $(77,78)$, thyrotoxic patients were rendered euthyroid with antithyroid drugs at the time of ${ }^{131}$ I treatment. Thus, in studies using a valid means of thyroid monitoring $(69,77,78)$, the goitre reduction of $30-40 \%$ on average was reasonably uniform; however, great individual variations were seen in all series. Follow-up with CT or MRI was limited to 1 year, but one report suggested that the reduction in these large goitres might continue beyond this period (79). It has been demonstrated, by MRI monitoring, that ${ }^{131}$ I therapy results in a similar reduction of the substernal and the cervical goitre component (80). Quantification of subjective improvement after high- 
dose ${ }^{131}$ I therapy has been only scant. Huysmans et al. (78) reported that $67 \%$ of the patients improved or were cured of dyspnoea or stridor, and even more were relieved of dysphagia. In other studies $(69,76$, 77 ), the vast majority of patients reported satisfaction with the outcome of therapy.

There has been concern that an early ${ }^{131}$ I-induced thyroid oedema may give rise to further enlargement of the goitre. In multinodular goitres, of both moderate and large size, it has been shown that ${ }^{131}$ I does not cause any significant increase in goitre size - on average - in the weeks after therapy $(77,81)$. Nevertheless, a 15\% increment in size of very large goitres may occasionally be seen within the first week (77) (Fig. 3), and at present it is impossible to predict in whom this complication may occur. Therefore, caution should always be taken if severe tracheal compression is present. In such cases, use of glucocorticoids to reduce inflammatory oedema might be considered for a short period after ${ }^{131}$ I therapy, although no studies have conclusively proven the efficacy of this strategy.

The thyroid ${ }^{131}$ I uptake is inversely correlated with the iodine pool in the organism. Use of ${ }^{131} \mathrm{I}$ therapy in large goitres is therefore hampered in some areas of the world where the dietary iodine content is high, as a large amount of radioactivity is needed to obtain an equivalent effect. If high-dose ${ }^{131} \mathrm{I}$ is administered in divided doses, admission of the patient to hospital required by official regulations - can be avoided. In the case of smaller goitres, a second ${ }^{131}$ I dose causes a further reduction of the goitre (82). In patients with large goitres, Howarth et al. (83) have shown that four doses, each of $555 \mathrm{MBq}(15 \mathrm{mCi})$, given 1 month apart, resulted in a goitre reduction in $92 \%$ of patients. However, the effect was assessed only clinically, and the ${ }^{131}$ I uptake at each treatment was not measured. Although data are few, divided therapy might be an option, but the doses probably should be given at

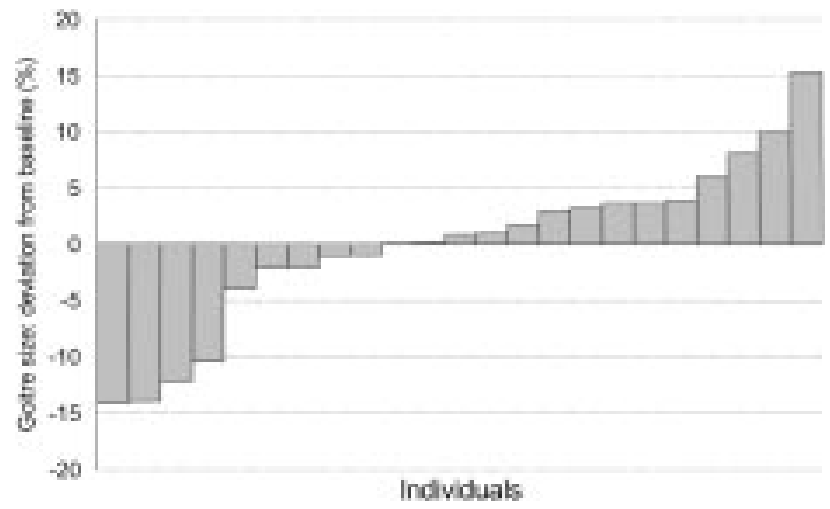

Figure 3 Relative changes in the volume of large goitres 1 week after high-dose ${ }^{131}$ I therapy in 23 patients. On average, no change in goitre size was seen. Derived from Bonnema et al. (77) with kind permission from the Endocrine Society. long intervals, which makes this treatment modality even more cumbersome.

\section{Impact of the large goitre on the trachea and effect of therapy}

The most serious problem caused by the large goitre is tracheal compression, and the upper airways (i.e. trachea) should be paid special attention, particularly if ${ }^{131}$ I therapy is considered. A clinically significant deterioration in ventilation is common among patients with a goitre, even if no symptoms are present (84). Although many factors influence inspiratory capacity, the size of the goitre no doubt has a major role, and a correlation between MRI estimates of the smallest tracheal cross-sectional area and inspiratory capacity may indeed be present in very large goitres (77). ${ }^{131} \mathrm{I}$ therapy has been shown to have a favourable effect on both inspiration and tracheal anatomy $(77,78$, $85)$. When large goitres are being treated, the smallest tracheal cross-sectional area, estimated by MRI, diminishes by approximately 9\% shortly after ${ }^{131} \mathrm{I}$ therapy, as a result of radiation-induced thyroid oedema, without a significant deterioration in inspiratory capacity (77) (Fig. 4). In the long term, the tracheal area increases by $17-36 \%(77,78)$ (Fig. 4), the tracheal deviation decreases by $20 \%$ (78), and inspiration improves by more than 20\% (77) (Fig. 4). However, with more than a $10 \%$ coefficient of variation (67), MRI measurements of tracheal structures are imprecise. Therefore, in the evaluation of the large goitre, a flow-volume loop should be considered before ${ }^{131}$ I therapy.

\section{What factors predict the efficacy of ${ }^{131}$ I therapy?}

In moderately enlarged, non-toxic multinodular goitres, the effect of ${ }^{131}$ I therapy on goitre reduction seems to correlate inversely with the initial size (82). Theoretically, such a relationship is plausible, because a larger fraction of the gland degenerates in the voluminous multinodular goitre. Indeed, an attenuation of the ${ }^{131}$ I effect as a function of the initial goitre size was demonstrated in the study by Bonnema et al. (77) (Fig. 5). It is natural to expect the reduction of the goitre to be amplified by increasing the ${ }^{131}$ I dose. Such a relationship was suggested by the studies of Le Moli et al. (82) and de Klerk et al. (69), but could not be confirmed in the study of Bonnema et al. (77). This inconsistency probably reflects the fact that thyroid ${ }^{131}$ I uptake varies with time (86), and the iodine biokinetics is probably also affected by the ${ }^{131}$ I treatment itself. The recent advent of recombinant human TSH (rhTSH), which can double the 24 -h thyroid ${ }^{131} \mathrm{I}$ uptake, opens up new possibilities (87). Whether this amplifies the reduction of the goitre after ${ }^{131}$ I therapy also is as yet unknown. 

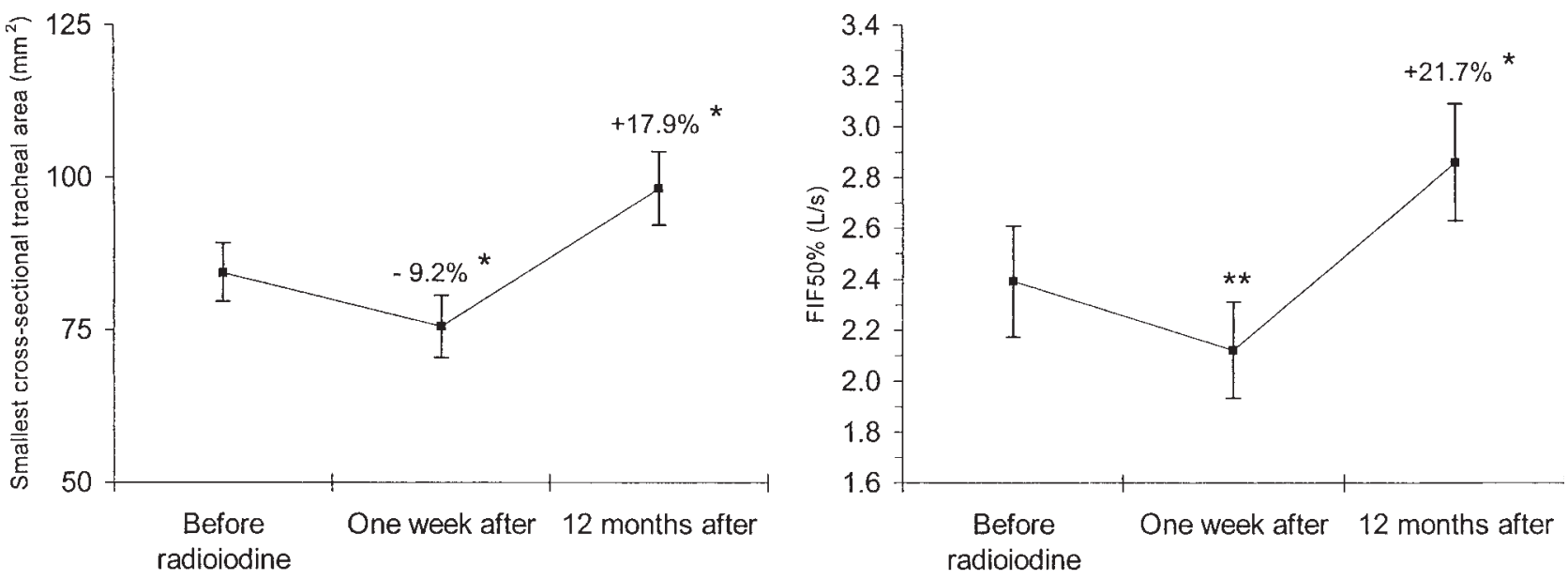

Figure 4 Effect of high-dose ${ }^{131} \mathrm{I}$ treatment of large goitres on the smallest cross-sectional area of the trachea and on forced inspiratory flow at $50 \%$ of the vital capacity (FIF50\%). ${ }^{\star} P<0.01,{ }^{\star \star} P=$ ns compared with baseline. Derived from Bonnema et al. (77).

\section{Adverse effects of ${ }^{131}$ I therapy}

Generally, ${ }^{131}$ I treatment of multinodular goitres is well tolerated. The small risk of a radiation-induced thyroiditis and transition into Graves' disease (88), occasionally including ophthalmopathy (89), is probably no different when high-dose ${ }^{131} \mathrm{I}$ is used. In smaller multinodular goitres, the incidence of permanent hypothyroidism after ${ }^{131}$ I therapy ranges from 6 to $58 \%$ $(70,72,82)$. In studies of large goitres treated with high-dose ${ }^{131} \mathrm{I}$, the 1 -year cumulated risk of hypothyroidism was $14-22 \%(69,77)$. Theoretically, the risk of hypothyroidism should not be affected by the large or small nature of the goitre being treated, as the targeted absorbed thyroid dose (approximately 100 Gray) usually is the same.

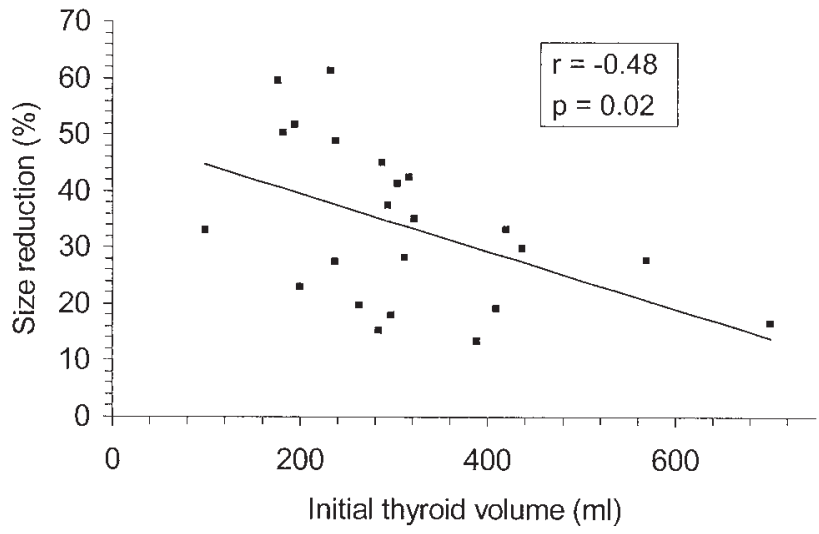

Figure 5 Initial volumes of large goitres estimated by MRI and the percent reduction 1 year after high-dose ${ }^{131}$ I therapy. Mean reduction was $34 \%$, but with increasing goitre size the effect was attenuated. Derived from Bonnema et al. (77) with kind permission from the Endocrine Society.
Long-term follow-up of patients with Graves' disease has not revealed any clinically significant increased risk of cancer after ${ }^{131} \mathrm{I}$ (90), but data on multinodular goitre are more scant. In a study by Ron et al. (91), 1089 patients were treated with ${ }^{131}$ I for a toxic nodular goitre, and these patients had a $31 \%$ increase in overall cancer mortality, nearly exclusively attributable to thyroid malignancy. However, a similar pattern was seen in patients with the same disease but not treated with ${ }^{131} \mathrm{I}$. The findings of a recent study (92) including more than 5000 patients previously treated with ${ }^{131} \mathrm{I}$ for toxic nodular thyroid diseases are reassuring, as no significantly increased incidence of thyroid cancers was found during the 27 years of follow-up. However, the absolute number of cancers that may occur after ${ }^{131}$ I therapy is small and seems of minor clinical importance. Furthermore, the disclosure of a thyroid cancer in a nodular goitre after ${ }^{131}$ I therapy raises the question whether malignancy in a nodule was overlooked at the time of therapy. With regard to high-dose ${ }^{131}$ I treatment, even fewer data are available. Huysmans et al. (93) estimated the theoretical overall lifetime risk of an extrathyroidal cancer caused by highdose ${ }^{131}$ I therapy to be $1.6 \%$, and $0.5 \%$ in elderly persons. Until long-term follow-up studies have described the actual cancer risk, high-dose ${ }^{131}$ I therapy should be restricted to only elderly persons, or to those in whom surgery is absolutely contraindicated.

\section{Concluding remarks}

Surgery is the treatment of first choice in patients with a large goitre, but high-dose ${ }^{131}$ I therapy may be an option in selected cases (Table 2). This latter treatment has a favourable effect on tracheal compression and inspiratory capacity, but the reduction in thyroid volume of $30-40 \%$ is less than that obtained in smaller 
Table 2 Advantages and disadvantages of the three main options available for treatment of the large goitre.

\begin{tabular}{|c|c|c|}
\hline & Advantages & Disadvantages \\
\hline Surgery & $\begin{array}{l}\text { Rapid decompression of trachea } \\
\text { Prompt relief of symptoms } \\
\text { Significant goitre reduction } \\
\text { Confirmation of benign disease }\end{array}$ & $\begin{array}{l}\text { Admission to hospital } \\
\text { Destructive therapy } \\
\text { Surgical complications: } 3-4 \% \\
\text { Risk of hypothyroidism } \\
\text { Risk of recurrence }\end{array}$ \\
\hline Radioiodine & $\begin{array}{l}\text { Few subjective side effects during treatment } \\
30-40 \% \text { goitre reduction within } 1 \text { year } \\
\text { Improves inspiratory capacity in long term } \\
\text { Can probably be repeated successfully }\end{array}$ & $\begin{array}{l}\text { Admission to hospital according to regulations } \\
\text { Gradual reduction of the goitre } \\
\text { Occasional risk of acute goitre enlargement } \\
\text { Occasional risk of transient thyrotoxicosis } \\
5 \% \text { risk of transition into Graves' disease } \\
1 \text {-year risk of hypothyroidism: } 15-20 \% \\
\text { Long-term cancer risk unknown }\end{array}$ \\
\hline L-Thyroxine & $\begin{array}{l}\text { Non-destructive therapy } \\
\text { No admission to hospital }\end{array}$ & $\begin{array}{l}\text { Life-long treatment } \\
\text { Limited efficacy, if any } \\
\text { Adverse effects (bone, heart) } \\
\text { Not feasible in hyperthyroidism }\end{array}$ \\
\hline
\end{tabular}

glands. Future studies will show if the effect can be reinforced, for example by pretreatment with rhTSH.

\section{Acknowledgements}

This work was supported by grants from The Agnes and Knut Mørks Foundation and The A P Møller Relief Foundation to Steen Bonnema and Laszlo Hegedüs, and by grants from the University of Insubria, Varese, Italy (Fondi d'Ateneo per la Ricerca) to Luigi Bartalena.

\section{References}

1 Glinoer D, Hesch D, Lagasse R \& Laurberg P. The management of hyperthyroidism due to Graves' disease in Europe in 1986. Results of an international survey. Acta Endocrinologica 1987285 (Suppl) $3-23$.

2 Solomon B, Glinoer D, Lagasse R \& Wartofsky L. Current trends in the management of Graves' disease. Journal of Clinical Endocrinology and Metabolism 199070 1518-1524.

3 Weetman AP \& Wiersinga WM. Current management of thyroidassociated ophthalmopathy in Europe. Results of an international survey. Clinical Endocrinology 199849 21-28.

4 Bennedbæk FN, Perrild H \& Hegedüs L. Diagnosis and treatment of the solitary thyroid nodule. Results of a European survey. Clinical Endocrinology 199950 357-363.

5 Bennedbæk FN \& Hegedüs L. Management of the solitary thyroid nodule: a North American survey. Journal of Clinical Endocrinology and Metabolism 200085 2493-2498.

6 Bonnema SJ, Bennedbæk FN, Wiersinga WM \& Hegedüs L. Management of the nontoxic multinodular goitre: a European questionnaire study. Clinical Endocrinology 200053 5-12.

7 Bonnema SJ, Bennedbæk FN, Ladenson PW \& Hegedüs L. Management of the nontoxic multinodular goiter: a North American survey. Journal of Clinical Endocrinology and Metabolism 200287 112-117.

8 Marcocci C, Bartalena L, Bogazzi F, Panicucci M \& Pinchera A. Studies on the occurrence of ophthalmopathy in Graves' disease. Acta Endocrinologica 1989120 473-478.
9 Marcocci C, Bartalena L, Bogazzi F, Bruno-Bossio G \& Pinchera A. Relationship between Graves' ophthalmopathy and type of treatment of Graves' hyperthyroidism. Thyroid 19922 171-178.

10 Bartalena L, Pinchera A \& Marcocci C. Management of Graves' ophthalmopathy: reality and perspectives. Endocrine Reviews 200021 168-199.

11 Marcocci C, Bruno-Bossio G, Manetti L, Tanda ML, Miccoli P, Iacconi P et al. The course of Graves' ophthalmopathy is not influenced by near total thyroidectomy: a case-control study. Clinical Endocrinology 199951 503-508.

12 Gorman CA. Therapeutic controversies. Radioiodine therapy does not aggravate Graves' ophthalmopathy. Journal of Clinical Endocrinology and Metabolism 199580 340-342.

13 Pinchera A, Bartalena L \& Marcocci C. Therapeutic controversies. Radioiodine may be bad for Graves' ophthalmopathy, but... Journal of Clinical Endocrinology and Metabolism $1995 \mathbf{8 0}$ 342-345.

14 Bartalena L, Marcocci C \& Pinchera A. Radioiodine therapy and Graves' opthalmopathy. In Graves' Disease - Pathogenesis and Treatment, pp 279-288. Eds B Rapoport \& SM McLachlan. Boston: Kluwer Academic Publishers, 2000.

15 Werner SC, Coelho B \& Quimby EH. Ten year results of I-131 therapy in hyperthyroidism. Bulletin of the New York Academy of Medicine 195733 783-806.

16 Hamilton HE, Schutz RO \& Gowil EL. The endocrine eye lesion in hyperthyroidism. Archives of Internal Medicine 1960105 675-685.

17 Pequegnat EP, Mayberry WE, McConahey WM \& Wyse EP. Large doses of radioiodine in Graves' disease: effects on ophthalmopathy and long-acting thyroid stimulator. Mayo Clinic Proceedings 1967 42 802-811.

18 Kriss JP, Pleshakov V, Rosenblum AL, Holderness M, Sharp G \& Utiger RD. Studies on the pathogenesis of the ophthalmopathy of Graves' disease. Journal of Clinical Endocrinology and Metabolism $196727582-593$.

19 Hetzel BS, Mason EK \& Kwan WH. Studies of serum long-acting thyroid stimulator (LATS) in relation to exophthalmos after therapy for thyrotoxicosis. Australasian Annals of Medicine 1967 17 307-311.

20 Barth A, Probst P \& Burgi H. Identification of a subgroup of Graves' disease patients at higher risk for severe ophthalmopathy after radioiodine. Journal of Endocrinological Investigation $1989 \mathbf{1 4}$ 209-212.

21 Fernandez-Sanchez JR, Rosell Pradas J, Carazo Martinez O, Torres Vela E, Escobar Jimenez F, Garbin Fuentes L et al. Graves' 
ophthalmopathy after subtotal thyroidectomy and radioiodine therapy. British Journal of Surgery 199380 1134-1136.

22 Kung AWC, Yau CC \& Cheng A. The incidence of ophthalmopathy after radioiodine therapy for Graves' disease: prognostic factors and the role of methimazole. Journal of Clinical Endocrinology and Metabolism 199479 542-546.

23 Aron-Rosa D, Perez R \& Abitbol Y. Malignant exophthalmos after iodine-131 treatment. Modern Problems in Ophthalmology 1975 14 432-434.

24 Sridama V \& DeGroot LJ. Treatment of Graves' disease and the course of ophthalmopathy. American Journal of Medicine 1989 87 70-73.

25 Abe Y, Sato H, Noguchi M, Mimura T, Sugino K, Ozaki O et al Effect of subtotal thyroidectomy on natural history of ophthalmopathy in Graves' disease. World Journal of Surgery 199822 714-717.

26 Manso PG, Furlanetto RP, Wolosker AMB, Paiva ER, de Abreu MT \& Maciel RMB. Prospective and controlled study of ophthalmopathy after radioiodine therapy for Graves' hyperthyroidism. Thyroid $1998 \mathbf{8} 49-52$.

27 Bartalena L, Marcocci C, Bogazzi F, Panicucci M, Lepri A \& Pinchera A. Use of corticosteroids to prevent progression of Graves' ophthalmopathy after radioiodine therapy for hyperthyroidism. New England Journal of Medicine 1989321 1349-1352.

28 Tallstedt L, Lundell G, Torring O, Wallin G, Ljunggren J-G, Blomgren $\mathrm{H}$ et al. Occurrence of ophthalmopathy after treatment for Graves' hyperthyroidism. The Thyroid Study Group. New England Journal of Medicine 1992326 1733-1738.

29 Bartalena L, Marcocci C, Bogazzi F, Manetti L, Tanda ML, Dell'Unto E et al. Relation between therapy for hyperthyroidism and the course of Graves' ophthalmopathy. New England Journal of Medicine 1998338 73-78.

30 Vàzquez-Chavez C, Nishimura Megara E, Espinosa Said L, Delgado Falfari A \& Sàinz de Viteri M. Influencia del tratamento del hipertiroidismo en el curso del exoftalmos (Effect of the treatment of hyperthyroidism on the course of exophthalmos). Revista de Investigacion Clinica $1992 \mathbf{4 4}$ 241-247.

31 Ozata M, Bayhau H, Bingol N, Dundar S, Beyhan Z, Corakci A et al. Sequential changes in serum thyroid peroxidase following radioiodine therapy of patients with differentiated thyroid carcinoma. Journal of Clinical Endocrinology and Metabolism $1995 \mathbf{8 0}$ $3634-3638$.

32 Fenzi GF, Hashizume K, Roudebush C \& DeGroot LJ. Changes in thyroid-stimulating immunoglobulins during antithyroid therapy. Journal of Clinical Endocrinology and Metabolism $1979 \quad \mathbf{4 8}$ 572-576.

33 Teng W-P, Stark R, Munro AJ, Young SM, Borysiewicz LK \& Weetman AP. Peripheral blood T cell activation after radioiodine treatment for Graves' disease. Acta Endocrinologica 1990122 233-240.

34 Aizawa Y, Yoshida K, Kaise N, Fukazawa H, Kiso Y, Mori K et al. Long-term effects of radioiodine on thyrotrophin receptor antibodies in Graves' disease. Clinical Endocrinology 19954 517-522.

35 Bartalena L, Marcocci C, Tanda ML, Manetti L, Dell'Unto E, Bartolomei MP et al. Cigarette smoking and treatment outcomes in Graves' ophthalmopathy. Annals of Internal Medicine 1998 $129632-635$.

36 Karlsson AF, Dahlberg PA, Jansson R, Westermark K \& Enoksson P. Importance of TSH receptor activation in the development of severe endocrine ophthalmopathy. Acta Endocrinologica 1989 121 (Suppl 2) 132-141.

37 Tallstedt L, Lundell G, Blomgren H \& Bring J. Does early administration of thyroxine reduce the development of Graves ophthalmopathy after radioiodine treatment? European Journal of Endocrinology 1994130 494-497.

38 Bartalena L, Marcocci C \& Pinchera A. Treating severe Graves' ophthalmopathy. Bailliere's Clinical Endocrinology and Metabolism 199711 521-536.

39 Wiersinga WM. Preventing Graves' ophthalmopathy. New England Journal of Medicine 1998338 121-122.
40 Shafer RB \& Nuttall FQ. Acute changes in thyroid function in patients treated with radioactive iodine. Lancet 1975 ii 635-637.

41 Burch HB, Solomon BL, Cooper DS, Feguson P, Walpert N \& Howard R. The effect of antithyroid drug pretreatment on acute changes in thyroid hormone levels after ${ }^{131} \mathrm{I}$ ablation for Graves' disease. Journal of Clinical Endocrinology and Metabolism 200186 3016-3021.

42 Larsen PR. Thyroidal triiodothyronine and thyroxine in Graves' disease: correlation with presurgical treatment, thyroid status and iodine content. Journal of Clinical Endocrinology and Metabolism 197541 1098-1104.

43 Williams RH, Towery BT, Jaffe H, Rogers WF \& Tagnon R. Radiotherapeusis. American Journal of Medicine 19497 702-717.

44 Mole RH, Philpot JST \& Hodges GRV. Reduction in lethal effect of X-radiation by pretreatment with thiourea or sodium ethane dithiophosphonate. Nature 1950166515.

45 Forssberg A. On the possibility of protecting the living organism against roentgen rays by chemical means. Acta Radiologica $195033296-304$

46 Crooks J, Buchanan WW, Wayne EJ \& MacDonald E. Effect of pretreatment with methylthiouracil on results of ${ }^{131}$ I therapy. British Medical Journal 19601 151-154.

47 Einhorn J \& Saterborg N-E. Antithyroid drugs in iodine-131 therapy of hyperthyroidism. Acta Radiologica 196258 161-167.

48 Tuttle RM, Patience T \& Budd S. Treatment with propylthiouracil before radioactive iodine therapy is associated with a higher treatment failure rate than therapy with radioactive iodine alone in Graves' disease. Thyroid 19955 243-247.

49 Hancock LD, Tuttle RM, LeMar H, Bauman J \& Patience T. The effect of propylthiouracil on subsequent radioactive iodine therapy in Graves' disease. Clinical Endocrinology $1997 \mathbf{4 7}$ 425-430.

50 Imseis RE, Vanmiddlesworth L, Massie JD, Bush AJ \& Vanmiddlesworth NR. Pretreatment with propylthiouracil but not methimazole reduces the therapeutic efficacy of iodine-131 in hyperthyroidism. Journal of Clinical Endocrinology and Metabolism $199883685-687$.

51 Goolden AWG \& Fraser TR. Effect of pretreatment with carbimazole in patients with thyrotoxicosis subsequently treated with radioactive iodine. British Medical Journal 19693 443-444.

52 Andrade VA, Gross JL \& Maia AL. The effect of methimazole pretreatment on the efficacy of radioiodine therapy in Graves' hyperthyroidism: one-year follow-up of a prospective, randomized study. Journal of Clinical Endocrinology and Metabolism 200186 3488-3493.

53 Sabri O, Zimny M, Schulz G, Schreckenberger M, Reinartz P, Willmes K et al. Success rate of radioiodine therapy in Graves' disease; the influence of thyrostatic medication. Journal of Clinical Endocrinology and Metabolism 199984 1229-1233.

54 Velkeniers B, Cytryn R, Vanhaelst L \& Jonckheer MH. Treatment of hyperthyroidism with radioiodine: adjunctive therapy with antithyroid drugs reconsidered. Lancet 1988 i 1127-1129.

55 Kampmann JP \& Hansen JM. Clinical pharmacokinetics of antithyroid drugs. Clinical Pharmacokinetics 19816 401-428.

56 Marchant B, Alexander WD, Lazarus JH, Lees J \& Clark DH. The accumulation of ${ }^{35} \mathrm{~S}$-antithyroid drugs by the thyroid gland. Journal of Clinical Endocrinology and Metabolism $1972 \mathbf{3 4}$ $847-851$.

57 Jansson R, Dahlberg PA, Johansson H \& Lindström B. Intrathyroidal concentrations of methimazole in patients with Graves' disease. Journal of Clinical Endocrinology and Metabolism 1983 57 129-132.

58 al Suliman NN, Ryttov NF, Qvist N, Blichert-Toft M \& Graversen HP. Experience in a specialist thyroid surgery unit: a demographic study, surgical complications, and outcome. European Journal of Surgery 1997163 13-20.

59 Tollin SR, Mery GM, Jelveh N, Fallon EF, Mikhail M, Blumenfeld W et al. The use of fine-needle aspiration biopsy under ultrasound guidance to assess the risk of malignancy in patients with a multinodular goiter. Thyroid $200010235-241$. 
60 Singer PA, Cooper DS, Daniels GH, Ladenson PW, Greenspan FS, Levy EG et al. Treatment guidelines for patients with thyroid nodules and well-differentiated thyroid cancer. Archives of Internal Medicine 1996156 2165-2172.

61 Wesche MF, Tiel-Van Buul MM, Lips P, Smits NJ \& Wiersinga WM. A randomized trial comparing levothyroxine with radioactive iodine in the treatment of sporadic nontoxic goiter. Journal of Clinical Endocrinology and Metabolism $200186998-1005$.

62 Berghout A, Wiersinga WM, Drexhage HA, Smits NJ \& Touber JL. Comparison of placebo with L-thyroxine alone or with carbimazole for treatment of sporadic non-toxic goitre. Lancet 1990 336 193-197.

63 Hegedüs L, Nygaard B \& Hansen JM. Is routine thyroxine treatment to hinder postoperative recurrence of nontoxic goiter justified? Journal of Clinical Endocrinology and Metabolism $1999 \mathbf{8 4}$ 756-760.

64 Roejdmark J \& Jaerhult J. High long term recurrence rate after subtotal thyroidectomy for nodular goitre. European Journal of Surgery $1995 \mathbf{1 6 1} 725-727$.

65 Jarløv AE, Hegedüs L, Gjørup T \& Hansen JM. Observer variation in the clinical assessment of the thyroid gland. Journal of Internal Medicine 1991229 159-161.

66 Jarløv AE, Hegedüs L, Gjørup T \& Hansen JE. Accuracy of the clinical assessment of thyroid size. Danish Medical Bulletin 1991 38 87-89.

67 Bonnema SJ, Andersen PB, Knudsen DU \& Hegedüs L. MR imaging of large multinodular goiters: observer agreement on volume versus observer disagreement on dimensions of the involved trachea. American Journal of Roentgenology 2002 (In Press).

68 Huysmans DA, de Haas MM, van den Broek WJ, Hermus AR, Barentsz JO, Corstens FH et al. Magnetic resonance imaging for volume estimation of large multinodular goitres: a comparison with scintigraphy. British Journal of Radiology 199467 519-523.

69 de Klerk JM, Van Isselt JW, van Dijk A, Hakman ME, Pameijer FA, Koppeschaar HP et al. Iodine-131 therapy in sporadic nontoxic goiter. Journal of Nuclear Medicine 199738 372-376.

70 Nygaard B, Hegedüs L, Ulriksen P, Nielsen KG \& Hansen JM. Radioiodine therapy for multinodular toxic goiter. Archives of Internal Medicine 1999159 1364-1368.

71 Hegedüs L, Hansen BM, Knudsen N \& Hansen JM. Reduction of size of thyroid with radioactive iodine in multinodular non-toxic goitre. British Medical Journal 1988297 661-662.

72 Nygaard B, Hegedüs L, Gervil M, Hjalgrim H, Soe-Jensen P \& Hansen JM. Radioiodine treatment of multinodular non-toxic goitre. British Medical Journal 1993307 828-832.

73 Wesche MF, Buul MM, Smits NJ \& Wiersinga WM. Reduction in goiter size by ${ }^{131}$ I therapy in patients with non-toxic multinodular goiter. European Journal of Endocrinology 1995132 86-87.

74 Kay TW, d'Emden MC, Andrews JT \& Martin FI. Treatment of non-toxic multinodular goiter with radioactive iodine. American Journal of Medicine $1988 \mathbf{8 4} 19-22$.

75 Hamburger JI \& Hamburger SW. Diagnosis and management of large toxic multinodular goiters. Journal of Nuclear Medicine $198526888-892$.

76 Verelst J, Bonnyns M \& Glinoer D. Radioiodine therapy in voluminous multinodular non-toxic goitre. Acta Endocrinologica 1990 122 417-421.

77 Bonnema SJ, Bertelsen H, Mortensen J, Andersen PB, Knudsen DU, Bastholt L et al. The feasibility of high dose iodine 131 treatment as an alternative to surgery in patients with a very large goiter: effect on thyroid function and size and pulmonary function. Journal of Clinical Endocrinology and Metabolism $1999 \mathbf{8 4}$ 3636-3641.
78 Huysmans DA, Hermus AR, Corstens FH, Barentsz JO \& Kloppenborg PW. Large, compressive goiters treated with radioiodine. Annals of Internal Medicine 1994121 757-762.

79 Huysmans D, Hermus A, Edelbroek M, Barentsz J, Corstens F \& Kloppenborg P. Radioiodine for nontoxic multinodular goiter. Thyroid 19977 235-239.

80 Bonnema SJ, Knudsen DU, Bertelsen H, Mortensen J, Andersen $\mathrm{PB}$, Bastholt L et al. Does radioiodine therapy have an equal effect on substernal and cervical goiter volumes? Evaluation by magnetic resonance imaging. Thyroid 200212 313-317.

81 Nygaard B, Faber J \& Hegedüs L. Acute changes in thyroid volume and function following 131I therapy of multinodular goitre. Clinical Endocrinology $1994 \mathbf{4 1}$ 715-718.

82 Le Moli R, Wesche MF, Tiel-Van Buul MM \& Wiersinga WM. Determinants of longterm outcome of radioiodine therapy of sporadic non-toxic goitre. Clinical Endocrinology $1999 \mathbf{5 0}$ 783-789.

83 Howarth DM, Epstein MT, Thomas PA, Allen LW, Akerman R \& Lan L. Outpatient management of patients with large multinodular goitres treated with fractionated radioiodine. European Journal of Nuclear Medicine 199724 1465-1469.

84 Gittoes NJ, Miller MR, Daykin J, Sheppard MC \& Franklyn JA. Upper airways obstruction in 153 consecutive patients presenting with thyroid enlargement. British Medical Journal 1996312484.

85 Nygaard B, Soes-Petersen U, Høilund-Carlsen PF, Veje A, Holst PE, Vestergaard A et al. Improvement of upper airway obstruction after ${ }^{131}$ I-treatment of multinodular nontoxic goiter evaluated by flow volume loop curves. Journal of Endocrinological Investigation $19961971-75$.

86 Van Isselt JW, de Klerk JM, Koppeschaar HP \& Van Rijk PP. Iodine131 uptake and turnover rate vary over short intervals in Graves' disease. Nuclear Medicine Communications $200021609-616$.

87 Huysmans DA, Nieuwlaat W, Erdtsieck J, Schellekens AP, Bus JW, Bravenboer B et al. Administration of a single low dose of recombinant human thyrotropin significantly enhances thyroid radioiodine uptake in nontoxic nodular goiter. Journal of Clinical Endocrinology and Metabolism 200085 3592-3596.

88 Nygaard B, Knudsen JH, Hegedüs L, Scient AV \& Hansen JE. Thyrotropin receptor antibodies and Graves' disease, a sideeffect of ${ }^{131}$ I treatment in patients with nontoxic goiter. Journal of Clinical Endocrinology and Metabolism 199782 2926-2930.

89 Nygaard B, Metcalfe RA, Phipps J, Weetman AP \& Hegedüs L. Graves' disease and thyroid associated ophthalmopathy triggered by ${ }^{131}$ I treatment of non-toxic goiter. Journal of Endocrinological Investigation 199922 481-485.

90 Franklyn JA, Maisonneuve P, Sheppard M, Betteridge J \& Boyle P. Cancer incidence and mortality after radioiodine treatment for hyperthyroidism: a population-based cohort study. Lancet 1999 353 2111-2115.

91 Ron E, Doody MM, Becker DV, Brill AB, Curtis RE, Goldman MB et al. Cancer mortality following treatment for adult hyperthyroidism. Cooperative Thyrotoxicosis Therapy Follow-up Study Group. JAMA $1998 \mathbf{2 8 0} 347-355$.

92 Angusti T, Codegone A, Pellerito R \& Favero A. Thyroid cancer prevalence after radioiodine treatment of hyperthyroidism. Journal of Nuclear Medicine $2000 \mathbf{4 1} 1006-1009$.

93 Huysmans DA, Buijs WC, van de Ven MT, van den Broek WJ, Kloppenborg PW, Hermus AR et al. Dosimetry and risk estimates of radioiodine therapy for large, multinodular goiters. Journal of Nuclear Medicine $1996372072-2079$.

Received 23 January 2002

Accepted 22 April 2002 